\title{
FINE NEEDLE ASPIRATION CYTOLOGY OF LYMPH NODES WITH HISTOLOGICAL CORRELATION- A STUDY OF 1033 CONSECUTIVE CASES, A SOUTH INDIAN STUDY
}

\author{
Tejaswini Gudibande1, Aniruddha Udupa K², Rekha Puranik $B^{3}$ \\ 1 Pathologist, Department of Pathology, Apollo BGS Hospital, Mysore, Karnataka. \\ ${ }^{2}$ Assistant Professor, Department of Pulmonary Medicine, Subbaiah Institute of Medical Sciences, Shimoga, Karnataka. \\ 3 Professor, Department of Pathology, Karnataka Institute of Medical Sciences, Hubli, Karnataka.
}

\section{ABSTRACT}

\section{BACKGROUND}

Accurate diagnosis of lymphadenopathy is of utmost importance in planning proper therapeutic measures. This is possible with a multidimensional view of the problem facilitated by understanding of its clinical appearances, cytology, histology and other lab investigations before making a diagnosis.

Aims and Objectives- To evaluate the role of FNAC in diagnosis and management of lymphadenopathy- changing perspectives in view of better cytodiagnosis and fewer biopsies.

\section{MATERIALS AND METHODS}

All patients presenting to the cytology section with lymphadenopathy and reference material submitted to the Department of Pathology, KIMS, Hubli for cytopathological study during the period from December 2010 to May 2012 were included. FNAC was done using 23-gauge needle. Wright's stain and $\mathrm{H}$ and $\mathrm{E}$ was used for all specimens. Histopathological study was done whenever biopsy specimen was received and IHC study was employed whenever necessary.

Study Design- A cross-sectional study.

\section{RESULTS}

Among a total number of 1220 lymph node aspirates, adequate material was obtained in 1033 cases. The age range of the patients ranged from 6 months to 89 years and the male: female ratio was 1.43: 1. The cervical group of lymph nodes was the commonest site of involvement- 727 cases (70\%). Benign lesions were seen in 802 patients (78\%) and neoplastic lesions were seen in 231 patients (22\%). Interpretation: Biopsies from the corresponding lymph nodes were received in 22 cases. Cytohistological correlation was found in 12 out of 22 cases (66.67\%). Five cases of reactive lymphadenitis on cytology revealed tubercular lymphadenitis, non-Hodgkin's lymphoma (2), metastatic deposits and Castleman's disease. Accuracy for reactive lymphadenitis was $77.27 \%$. Accuracy of cytological diagnosis of Hodgkin's and non-Hodgkin's lymphoma were found to be $100 \%$ and $77.27 \%$ respectively. Maximum number of correct diagnosis was obtained in metastatic carcinoma. Overall, the accuracy of Cytohistological correlation was found to be $14 / 22$, i.e. $63.64 \%$.

\section{CONCLUSION}

Aspiration cytology provides a reliable, safe, rapid and economic method of investigating lymph node enlargement. However, reactive lymphadenitis/ a negative cytology does not rule out serious underlying disorder. This should be considered keeping the overall clinical picture in mind. Also, the diagnostic accuracy can be further improved manifold when used in collaboration with other special techniques like cytochemistry, bacteriologic culture, immunocytochemistry, ultrastructural studies and molecular hybridisation.

\section{KEYWORDS}

Lymph Nodes, FNAC, Histological Correlation.

HOW TO CITE THIS ARTICLE: Gudibande T, Udupa AK, Puranik RB. Fine needle aspiration cytology of lymph nodes with histological correlation- a study of 1033 consecutive cases, a South Indian study. J. Evolution Med. Dent. Sci. 2018;7(15):18491856, DOI: $10.14260 /$ jemds/2018/418

\section{BACKGROUND}

Accurate diagnosis of lymphadenopathy is of utmost importance in planning proper therapeutic measures. This is possible with a multidimensional view of the problem facilitated by understanding of its clinical appearances,

'Financial or Other Competing Interest': None.

Submission 22-02-2018, Peer Review 22-03-2018,

Acceptance 28-03-2018, Published 09-04-2018.

Corresponding Author:

Dr. Tejaswini Gudibande,

W/o. Dr. Adithya Udupa. $K$,

\#1519, $3^{\text {rd }}$ Main, $6^{\text {th }}$ Cross,

Vijayanagar $2^{\text {nd }}$ Stage, Mysore-570019,

Karnataka.

E-mail: autejaswini@gmail.com

DOI: $10.14260 /$ jemds $/ 2018 / 418$

\section{(c) $(1)$}

cytology, histology and other lab investigations before making a diagnosis. Even such an approach may fail to establish the aetiology in few cases. One of the most problematic areas in cytology is the distinction between a reactive and neoplastic lymphoid proliferation. ${ }^{1}$

The Department of Pathology, KIMS, Hubli receives a good number of patients with lymphadenopathy for cytodiagnosis. Hence, an attempt is made to study the different varieties of lymphadenopathy, which will bear impact on patient management and prognosis.

\section{Objectives}

To evaluate the role of FNAC in diagnosis and management of lymphadenopathy- changing perspectives in view of better cytodiagnosis and fewer biopsies. 


\section{Study Design}

A cross-sectional study.

\section{MATERIALS AND METHODS}

\section{Source of Data}

All patients presenting to the cytology section with lymphadenopathy and reference material submitted to the Department of Pathology, KIMS, Hubli for cytopathological study during the period from December 2010 to May 2012. FNAC was done with patient's verbal consent. Histopathological study of biopsy material of these cases was done wherever available.

\section{Methods of Collection of Data}

Clinical data was obtained from patient's examination, clinical records, lab investigations and requisition submitted for cytology of lymph nodes and tissue specimens received in the department for histopathological examination. The clinical and laboratory data of these patients were recorded on a structured proforma.

\section{Inclusion Criteria}

All patients presenting to the department with lymphadenopathy for FNAC study.

\section{Exclusion Criteria}

1. Cases where inadequate aspirate precludes diagnosis.

2. Cases under treatment for known primary or secondary neoplasm in lymph nodes.

\section{Technique of FNAC 2,3}

The aspiration procedure is simple and rapid, and inexpensively performed on both hospitalised and outpatients. Sedation or local anaesthesia is unnecessary. The largest and most prominent lymph node is selected. The selected lymph node is aspirated under strict aseptic precautions. Overlying skin is stretched, and the lymph node grasped between the index finger and thumb of left hand; a sterile 22 or 23 gauge needle is fitted to a $5-10 \mathrm{~mL}$ syringe and pierced obliquely into the lymph node. After entering the lymph node mass, the plunger is withdrawn, and the negative pressure created in the syringe. Then the needle is moved back and forth several times with a constant suction. The negative pressure is released, and the needle removed from the mass. Smears are prepared using another glass slide exerting light pressure.

Local lidocaine anaesthesia was used only when deep lesions were aspirated. A 20-cc glass syringe with an 18gauge, 1.5-inch long needle was used. For deep-seated softtissue, transthoracic or transabdominal masses, 35-inch spinal needles were used.

Smears are immediately fixed in 95\% ethyl alcohol and stained by Haematoxylin and eosin stain. Air-dried smears are also prepared and stained with Wright's stain. Other special stains used were Ziehl-Neelsen, Papanicolaou stain and GMS stain wherever necessary.
Histopathological study was done whenever biopsy specimen was received. IHC study, wherever necessary, was employed.

Ancillary studies like Mantoux test, haematological parameters and chest x-ray, serological tests for HIV, Brucella and bone marrow examination were done wherever necessary to arrive at a comprehensive diagnosis. In patients with source of infection, swab was taken for culture and sensitivity.

\section{Ethical Clearance}

Ethical clearance was obtained from Ethical Committee of our Institutes.

\section{RESULTS}

Total number of cases in the present study was 1220 . Inadequate or no aspirates were obtained in 187. Adequate history and aspirate were obtained in 1033 cases. 85 patients were HIV positive.

Male: female patients were in the ratio of $6: 4$. Incidence of malignant lesions was $23 \%$.

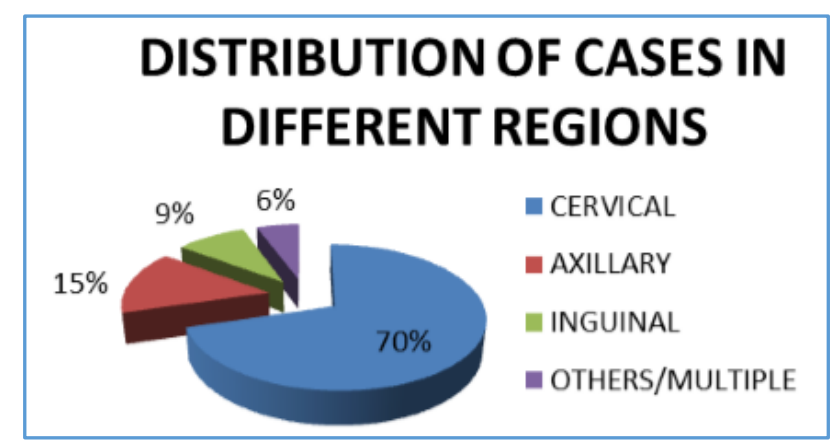

\section{Benign Lymphadenopathies}

- Reactive lymphadenitis was the most common lesion in the cervical and axillary region followed by tubercular lymphadenitis.

- Reactive lymphadenitis was the most common lesion in inguinal region.

\section{Malignant Lymphadenopathies}

Metastatic squamous cell carcinoma was the most common lesion in cervical region. The second most common was metastatic adenocarcinoma deposits and poorly differentiated carcinoma deposits. We encountered 4 cases suggestive of Hodgkin's lymphoma and 6 cases of NHL. Other malignant lesions were deposits of papillary carcinoma thyroid, mucoepidermoid carcinoma and renal cell carcinoma.

Metastatic adenocarcinoma was the most common malignant lesion in the axillary region, most often the primary was from infiltrating ductal carcinoma of breast. Metastatic squamous cell carcinoma was the most common malignancy in the inguinal region. 

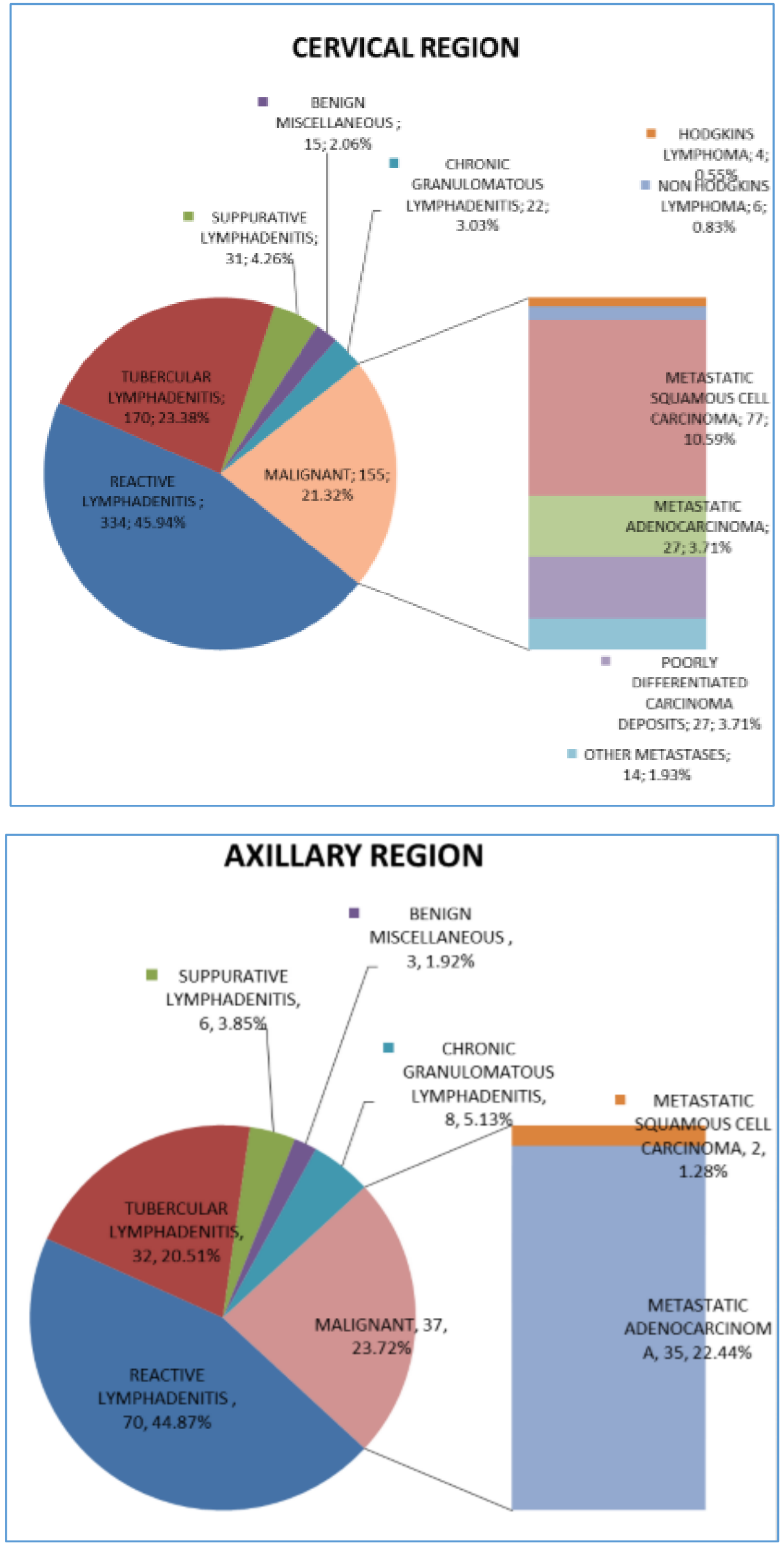


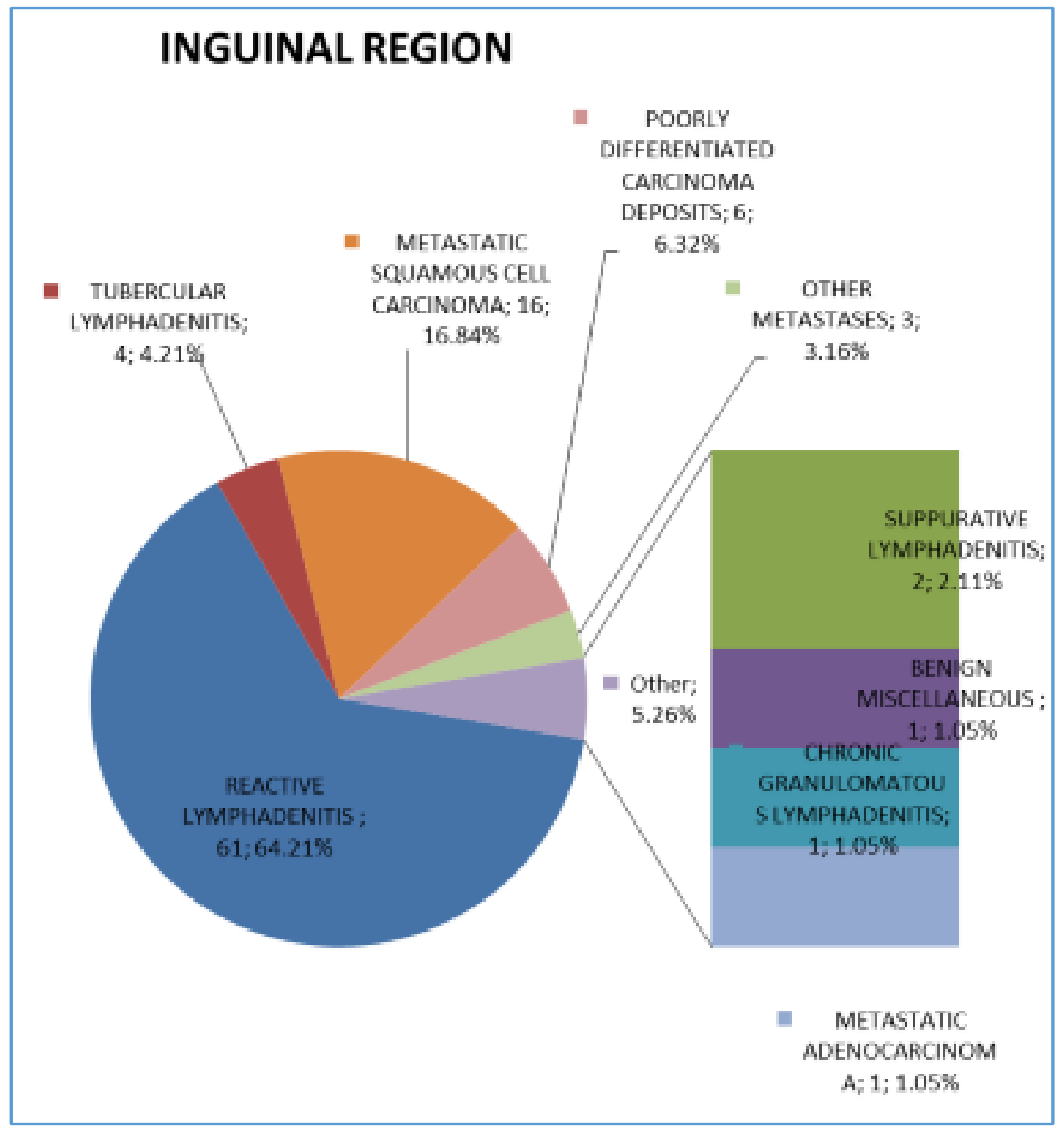

Biopsies were obtained in 22 Cases. Table Cytohistological Correlation A

\begin{tabular}{|c|c|c|c|c|c|c|}
\hline Sl. No. & Age & Sex & $\begin{array}{l}\text { Cytology } \\
\text { Diagnosis }\end{array}$ & $\begin{array}{c}\text { Biopsy } \\
\text { Diagnosis }\end{array}$ & $\mathbf{Y} / \mathbf{N}$ & $\begin{array}{c}\text { Final } \\
\text { Diagnosis (IHC Etc.) }\end{array}$ \\
\hline 1. & 55 & $\mathrm{~F}$ & $\begin{array}{c}\text { REACTIVE } \\
\text { LYMPHADENITIS }\end{array}$ & HODGKIN'S DISEASE & $\mathrm{N}$ & NHL- DLBCL \\
\hline 2. & 45 & $\mathrm{~F}$ & $\begin{array}{c}\text { REACTIVE } \\
\text { LYMPHADENITIS }\end{array}$ & $\begin{array}{l}\text { CASTLEMAN'S } \\
\text { DISEASE }\end{array}$ & Y & \\
\hline 3. & 30 & M & $\begin{array}{l}\text { POORLY DIFF CA } \\
\text { DEPOSITS }\end{array}$ & $\begin{array}{l}\text { NHL- SMALL CLEAVED CELL } \\
\text { TYPE }\end{array}$ & $\mathrm{N}$ & \\
\hline 4. & 65 & $\mathrm{~F}$ & ADENOCARCINOMA DEPOSITS & ADENOCARCINOMA DEPOSITS & $\mathrm{Y}$ & \\
\hline 5. & 25 & $\mathrm{~F}$ & NHL & DSRCT & $\mathrm{N}$ & DSRCT \\
\hline 6. & 40 & $\mathrm{~F}$ & $\begin{array}{c}\text { PAPILLARY CA } \\
\text { THYROID } \\
\end{array}$ & $\begin{array}{l}\text { PAPILLARY CA } \\
\text { THYROID } \\
\end{array}$ & Y & \\
\hline 7. & 35 & $\mathrm{~F}$ & $\begin{array}{l}\text { PAPILLARY CA } \\
\text { THYROID } \\
\end{array}$ & $\begin{array}{l}\text { PAPILLARY CA } \\
\text { THYROID } \\
\end{array}$ & Y & \\
\hline 8. & 60 & M & $\begin{array}{l}\text { POSSIBILITY OF NHL TO BE } \\
\text { CONSIDERED }\end{array}$ & CASEATING TUBERCULAR LN & $\mathrm{N}$ & \\
\hline 9. & 35 & $\mathrm{~F}$ & $\begin{array}{l}\text { GRANULOMATOUS } \\
\text { LYMPHADENITIS }\end{array}$ & $\begin{array}{l}\text { GRANULOMATOUS } \\
\text { LYMPHADENITIS }\end{array}$ & Y & \\
\hline 10. & 45 & $\mathrm{~F}$ & REACTIVE LYMPHADENITIS & REACTIVE LYMPHADENITIS & $\mathrm{Y}$ & \\
\hline 11. & 65 & $\mathrm{~F}$ & $\begin{array}{l}\text { METASTATIC SQ CELL } \\
\text { CARCINOMA } \\
\end{array}$ & $\begin{array}{l}\text { METASTATIC SQ CELL } \\
\text { CARCINOMA } \\
\end{array}$ & Y & \\
\hline 12. & 45 & $\mathrm{~F}$ & REACTIVE LYMPHADENITIS & REACTIVE LYMPHADENITIS & $\mathrm{N}$ & $\begin{array}{l}\text { SMALL LYMPHOCYTIC } \\
\text { LYMPHOMA }\end{array}$ \\
\hline 13. & 45 & $\mathrm{M}$ & REACTIVE LYMPHADENITIS & REACTIVE LYMPHADENITIS & $\mathrm{Y}$ & \\
\hline 14. & 50 & $\mathrm{M}$ & REACTIVE LYMPHADENITIS & REACTIVE LYMPHADENITIS & $\mathrm{Y}$ & \\
\hline 15. & 18 & $\mathrm{M}$ & HODGKIN'S LYMPHOMA & HODGKIN'S LYMPHOMA & $\mathrm{Y}$ & \\
\hline 16. & 40 & M & NHL & NHL & Y & $\begin{array}{c}\text { NHL- LOW-GRADE B-CELL } \\
\text { TYPE }\end{array}$ \\
\hline
\end{tabular}




\begin{tabular}{|c|c|c|c|c|c|c|}
\hline 17. & 47 & $\mathrm{M}$ & CASEATING TUBERCULAR LN & CASEATING TUBERCULAR LN & $\mathrm{Y}$ & \\
\hline 18. & 53 & $\mathrm{M}$ & REACTIVE LYMPHADENITIS & \begin{tabular}{|l} 
TUBERCULAR LYMPHADENITIS \\
\end{tabular} & $\mathrm{N}$ & \\
\hline 19. & 58 & M & REACTIVE LYMPHADENITIS & $\begin{array}{l}\text { MODERATELY DIFFERENTIATED } \\
\text { SQUAMOUS CELL CA }\end{array}$ & $\mathrm{N}$ & \\
\hline 20. & 50 & $\mathrm{~F}$ & REACTIVE LYMPHADENITIS & REACTIVE LYMPHADENITIS & $\mathrm{Y}$ & \\
\hline 21. & 52 & $\mathrm{~F}$ & $\begin{array}{l}\text { POORLY DIFFERENTIATED } \\
\text { CARCINOMA DEPOSITS }\end{array}$ & $\begin{array}{c}\text { METASTATIC } \\
\text { UNDIFFERENTIATED } \\
\text { CARCINOMA- PROBABLY } \\
\text { NASOPHARYNGEAL }\end{array}$ & $\mathrm{Y}$ & $\begin{array}{c}\text { METASTATIC } \\
\text { UNDIFFERENTIATED } \\
\text { CARCINOMA- UPPER } \\
\text { AERODIGESTIVE TRACT OR } \\
\text { SALIVARY DUCT CA } \\
\end{array}$ \\
\hline 22. & 17 & $\mathrm{M}$ & NHL & NHL & $\mathrm{Y}$ & \\
\hline
\end{tabular}

Table Overall Cytohistological Correlation

\begin{tabular}{|c|c|c|}
\hline & \multicolumn{2}{|c|}{ Histological Diagnosis } \\
\hline Cytological Diagnosis & Positive & Negative \\
\hline Positive & 14 & 2 \\
\hline Negative & 4 & 2 \\
\hline
\end{tabular}

Sensitivity $=14 / 18=77.78 \%$

Specificity $=2 / 4=50 \%$

$\mathrm{PPV}=14 / 16=87.5 \%$

$\mathrm{NPV}=2 / 6=33.34 \%$

Accuracy $=14 / 22=63.64 \%$

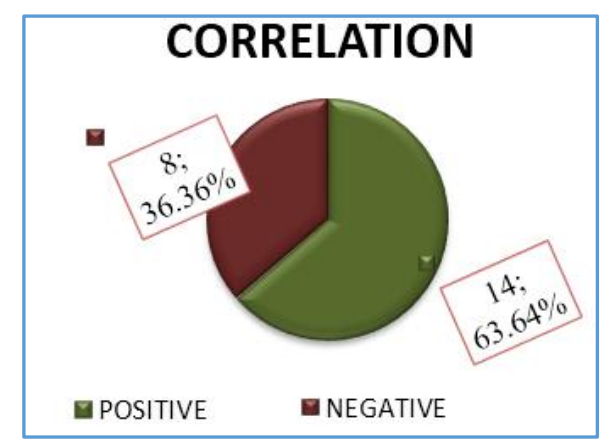

Overall the Accuracy of Cytohistological Correlation was found to be $14 / 22$, i.e. $63.64 \%$

Reactive Lymphadenitis/Cytohistological Correlation Four cases of reactive lymphadenitis, diagnosed on histopathology were also diagnosed on cytology.

5 cases reported as reactive on cytology showed features of tubercular lymphadenitis, Hodgkin's lymphoma, nonHodgkin's lymphoma, metastatic deposits of squamous cell carcinoma and Castleman's disease (one each) on histological examination. The case diagnosed as Hodgkin's lymphomamixed cellularity was diagnosed as diffuse large B-Cell lymphoma on IHC.

\section{Calculations for Reactive Lymphadenitis}

\begin{tabular}{|c|c|c|c|}
\hline & $\begin{array}{c}\text { Histopathology } \\
\text { Positive }\end{array}$ & $\begin{array}{c}\text { Histopathology } \\
\text { Negative }\end{array}$ & \\
\hline $\begin{array}{c}\text { Cytology } \\
\text { Positive }\end{array}$ & 4 & 5 & PPV $=\mathrm{a} / \mathrm{a}+\mathrm{b}$ \\
\hline $\begin{array}{c}\text { Cytology } \\
\text { Negative }\end{array}$ & 0 & 13 & NPV=d/c+d \\
\hline & $\begin{array}{c}\text { Sensitivity= } \\
\mathrm{a} / \mathrm{a}+\mathrm{c}\end{array}$ & $\begin{array}{c}\text { Specificity= } \\
{[\mathrm{d} / \mathrm{b}+\mathrm{d}]}\end{array}$ & $\begin{array}{c}\text { Accuracy }=\mathrm{a}+\mathrm{d} / \\
\mathrm{a}+\mathrm{b}+\mathrm{c}+\mathrm{d}\end{array}$ \\
\hline
\end{tabular}

Therefore, the sensitivity $=100 \%$

Specificity $=72.2 \%$

Accuracy $=77.27 \%$
Tubercular Lymphadenitis/ Cytohistological Correlation Two cases of tubercular lymphadenitis diagnosed on histopathology were also diagnosed on cytology.

An additional 2 cases were missed on cytology as reactive lymphadenitis and non-Hodgkin's lymphoma.

\section{Calculations for Tubercular Lymphadenitis}

\begin{tabular}{|c|c|c|c|}
\hline & $\begin{array}{c}\text { Histopathology } \\
\text { Positive }\end{array}$ & $\begin{array}{c}\text { Histopathology } \\
\text { Negative }\end{array}$ & \\
\hline $\begin{array}{c}\text { Cytology } \\
\text { Positive }\end{array}$ & 2 & 0 & PPV=a/a+b \\
\hline $\begin{array}{c}\text { Cytology } \\
\text { Negative }\end{array}$ & 2 & 18 & NPV=d/c+d \\
\hline & $\begin{array}{c}\text { Sensitivity }= \\
\mathrm{a} / \mathrm{a}+\mathrm{c}\end{array}$ & $\begin{array}{c}\text { Specificity }= \\
{[\mathrm{d} / \mathrm{b}+\mathrm{d}]}\end{array}$ & $\begin{array}{c}\text { Accuracy }=\mathrm{a}+\mathrm{d} / \\
\mathrm{a}+\mathrm{b}+\mathrm{c}+\mathrm{d}\end{array}$ \\
\hline
\end{tabular}

Therefore, the Sensitivity $=50 \%$

Specificity $=100 \%$

Accuracy $=90.91 \%$

Hodgkin's Lymphoma/ Cytohistological Correlation One case of Hodgkin's lymphoma diagnosed on histopathology was diagnosed on cytology.

\section{Calculations for Hodgkin's Lymphoma}

\begin{tabular}{|c|c|c|c|}
\hline & $\begin{array}{c}\text { Histopathology } \\
\text { Positive }\end{array}$ & $\begin{array}{c}\text { Histopathology } \\
\text { Negative }\end{array}$ & \\
\hline $\begin{array}{c}\text { Cytology } \\
\text { Positive }\end{array}$ & $1 \mathrm{a}$ & $0 \mathrm{~b}$ & $\mathrm{PPV}=\mathrm{a} / \mathrm{a}+\mathrm{b}$ \\
\hline $\begin{array}{c}\text { Cytology } \\
\text { Negative }\end{array}$ & $0 \mathrm{c}$ & $21 \mathrm{~d}$ & $\mathrm{NPV}=\mathrm{d} / \mathrm{c}+\mathrm{d}$ \\
\hline & $\begin{array}{c}\text { Sensitivity= } \\
\mathrm{a} / \mathrm{a}+\mathrm{c}\end{array}$ & $\begin{array}{c}\text { Specificity= } \\
{[\mathrm{d} / \mathrm{b}+\mathrm{d}]}\end{array}$ & $\begin{array}{c}\text { Accuracy }= \\
\mathrm{a}+\mathrm{d} / \\
\mathrm{a}+\mathrm{b}+\mathrm{c}+\mathrm{d}\end{array}$ \\
\hline
\end{tabular}

Therefore, the Sensitivity $=100 \%$

Specificity $=100 \%$

Accuracy $=100 \%$

Non-Hodgkin's Lymphoma/ Cytohistological Correlation Four cases of NHL diagnosed on histopathology were also diagnosed on cytology.

Three cases were missed on cytology as reactive lymphadenitis (2) and deposits of poorly differentiated carcinoma (1). Additional 2 cases reported as NHL on cytology showed features of tubercular lymphadenitis and Desmoplastic Small Round Cell Tumour on histological examination. One of the four cases diagnosed as non- 
Hodgkin's lymphoma was confirmed on IHC as NHL lowgrade B cell type.

Calculations for Non-Hodgkin's Lymphoma

\begin{tabular}{|c|c|c|c|}
\hline & $\begin{array}{c}\text { Histopathology } \\
\text { Positive }\end{array}$ & $\begin{array}{c}\text { Histopathology } \\
\text { Negative }\end{array}$ & \\
\hline $\begin{array}{c}\text { Cytology } \\
\text { Positive }\end{array}$ & 2 & 2 & PPV=a/a+b \\
\hline $\begin{array}{c}\text { Cytology } \\
\text { Negative }\end{array}$ & 3 & 15 & NPV $=\mathrm{d} / \mathrm{c}+\mathrm{d}$ \\
\hline & $\begin{array}{c}\text { Sensitivity }= \\
\mathrm{a} / \mathrm{a}+\mathrm{c}\end{array}$ & $\begin{array}{c}\text { Specificity }= \\
{[\mathrm{d} / \mathrm{b}+\mathrm{d}]}\end{array}$ & $\begin{array}{c}\text { Accuracy }=\mathrm{a}+\mathrm{d} / \\
\mathrm{a}+\mathrm{b}+\mathrm{c}+\mathrm{d}\end{array}$ \\
\hline
\end{tabular}

Therefore, the Sensitivity $=40 \%$

Specificity $=88.235 \%$

Accuracy $=77.27 \%$

\section{Metastatic Carcinoma Deposits/ Cytohistological} Correlation

Among them, one patient was positive for HIV. One case of deposits of squamous cell carcinoma was diagnosed on cytology and one was missed.

\section{Cytohistological Correlation}

Two cases had lymph node excised, among which one was diagnosed as NHL and other was diagnosed as metastatic deposits of undifferentiated carcinoma from upper aerodigestive tract.

\section{Calculations for Metastatic Deposits in Lymph Node}

\begin{tabular}{|c|c|c|c|}
\hline & $\begin{array}{c}\text { Histopathology } \\
\text { Positive }\end{array}$ & $\begin{array}{c}\text { Histopathology } \\
\text { Negative }\end{array}$ & \\
\hline $\begin{array}{c}\text { Cytology } \\
\text { positive }\end{array}$ & 5 & 1 & PPV $=\mathrm{a} / \mathrm{a}+\mathrm{b}$ \\
\hline $\begin{array}{c}\text { Cytology } \\
\text { negative }\end{array}$ & 1 & 15 & $\mathrm{NPV}=\mathrm{d} / \mathrm{c}+\mathrm{d}$ \\
\hline & Sensitivity=a/a+c & $\begin{array}{c}\text { Specificity }= \\
{[\mathrm{d} / \mathrm{b}+\mathrm{d}]}\end{array}$ & $\begin{array}{c}\text { Accuracy }= \\
\mathrm{a}+\mathrm{d} / \\
\mathrm{a}+\mathrm{b}+\mathrm{c}+\mathrm{d}\end{array}$ \\
\hline
\end{tabular}

Sensitivity $=5 /(5+1)=83.33 \%$

Specificity $=15 /(1+15)=93.75 \%$

Accuracy $=5+15 / 22=90.90 \%$

\section{Therefore, overall for Diagnosis of Metastatic Deposits}

- $\quad$ Sensitivity $=83.33 \%$

- $\quad$ Specificity $=93.75 \%$

- $\quad$ Accuracy $=90.90 \%$

\section{DISCUSSION}

Fine needle aspiration cytology is a useful adjunct to conventional method of diagnosis in cases of mass lesions. It is a simple, cost effective, safe and time saving procedure. Lymphadenopathy is one of the common clinical presentations of various ongoing disease processes inside the body. The aim of the present study was to evaluate the role of FNAC in cases of lymphadenopathy of various aetiologies, to find the frequency and cause of lymph node enlargement in patients of different age groups and analyse the different cytomorphological patterns associated with various lymphadenopathies.
The results in this study show that fine needle aspiration cytology is a useful adjunct to clinical diagnosis for triage of patients into those who require biopsy. Fine needle aspiration cytology was performed in 1220 cases of lymphadenopathy, both superficial and deep.

The lesions arising in the lymph node can be found in patients ranging from early to advanced age. In our study, the youngest patient was 6 months old, male, HIV positive with reactive lymphadenitis. The oldest was 89 years old female with metastatic squamous cell carcinoma deposits in cervical lymph node from primary in the cheek. These figures come in close comparison to other studies. ${ }^{4,5}$

The male preponderance (59\%) in our series correlates well with studies done by Agarwal ${ }^{4}$ (57.2\%), whereas maleto-female ratio was equal in other series by Hag et al. ${ }^{6}$ As regards to the site of FNAC, cervical region $(70 \%)$ was the commonest site of lymphadenopathy followed by axillary region (15\%) as observed by Ahamad SS et al, ${ }^{7}$ Hirachand et $\mathrm{al}^{8}$ and Agarwal et al. ${ }^{4}$

Comparison of Distribution in Different Regions in Different Studies

\begin{tabular}{|c|c|c|c|c|}
\hline Region & $\begin{array}{c}\text { Agarwal et } \\
\text { al }^{\mathbf{4}}\end{array}$ & $\begin{array}{c}\text { Ahamad SS } \\
\text { et al }^{\mathbf{7}}\end{array}$ & $\begin{array}{c}\text { Hirachand } \\
\text { et al }^{\mathbf{8}}\end{array}$ & $\begin{array}{c}\text { Present } \\
\text { Study }\end{array}$ \\
\hline Cervical & $91.1 \%$ & $73.5 \%$ & $75.4 \%$ & $70 \%$ \\
\hline Axillary & $5.78 \%$ & $10.6 \%$ & $15.4 \%$ & $15 \%$ \\
\hline Inguinal & --- & & $9.2 \%$ & $9 \%$ \\
\hline $\begin{array}{c}\text { Other/ } \\
\text { Multiple }\end{array}$ & $3.12 \%$ & $15.9 \%$ & -- & $6 \%$ \\
\hline
\end{tabular}

Out of total 1033 cases, 820 cases (78\%) were benign and 23 $(22 \%)$ were malignant lesions.

\section{Comparison of Diagnosis in Various Studies}

\begin{tabular}{|c|c|c|c|c|}
\hline $\begin{array}{c}\text { Cytologic } \\
\text { Diagnosis }\end{array}$ & $\begin{array}{c}\text { Ahmad SS } \\
\text { et al }^{7}\end{array}$ & $\begin{array}{c}\text { Hirachand } \\
\text { et al }^{8}\end{array}$ & $\begin{array}{c}\text { Agarwal } \\
\text { et al }^{4}\end{array}$ & $\begin{array}{c}\text { Present } \\
\text { Study }\end{array}$ \\
\hline Benign & $86.4 \%$ & $81.7 \%$ & $80.29 \%$ & $78 \%$ \\
Reactive & $53.6 \%$ & $41.5 \%$ & $42.15 \%$ & $47.53 \%$ \\
Tubercular & $32.8 \%$ & $28 \%$ & $27.19 \%$ & $20.53 \%$ \\
\hline Malignant & $13.6 \%$ & $18.3 \%$ & $19.71 \%$ & $22 \%$ \\
Primary & $4.5 \%$ & $6 \%$ & $2.1 \%$ & $1.74 \%$ \\
Metastasis & $9.1 \%$ & $12.3 \%$ & $17.6 \%$ & $20.36 \%$ \\
\hline
\end{tabular}

Various causes have been found to be responsible for lymphadenopathy and their frequency varies according to the age of the patient. Out of the total 1033 patients, the most common aetiological factor in lymphadenopathy was reactive lymphadenitis followed by tubercular lymphadenitis which is comparable with studies done by Aggarwal et al,4 Ahmad et $\mathrm{al}^{7}$ and Hirachand et al. ${ }^{8}$

As in the present study, Hirachand et $\mathrm{al}^{8}$ and Hadju et $\mathrm{al}^{9}$ also noted that the commonest type of metastatic carcinoma to lymph node was of squamous cell variety (9.2\%) followed by adenocarcinoma (6.7\%). We encountered a lower incidence of lymphoma/ primary malignancies of lymph nodes compared to other studies, probably because ours is a tertiary care institute and not a referral centre for cancer. ${ }^{4,7,8}$

The most common tumour metastases to the neck nodes was the squamous cell carcinoma (10.6\%) arising commonly in the cheek, tongue, buccal mucosa, alveolus, palate and 
nasopharynx followed by adenocarcinoma (3.7\%) and poorly differentiated carcinoma deposits (3.7\%).

In the axillary region, metastatic adenocarcinoma from primary in the breast was the most common malignant lesion (22.4\%) similar to that noted by Gupta et al.10

In the non-Hodgkin's lymphoma group, 2 cases were of leukaemic infiltration in the lymph node. In such cases, it is very difficult to differentiate between non-Hodgkin's lymphoma and leukaemic infiltration on examination of cytological smears alone as noted by Pandit et al. ${ }^{11}$

\section{Comparison of Number of Biopsies in our Institute a Decade Ago}

\begin{tabular}{|c|c|c|}
\hline Time period & $2000-02$ & $2010-12$ \\
\hline $\begin{array}{c}\text { Number of lymph node biopsies received } \\
\text { in the department }\end{array}$ & 311 & 22 \\
\hline
\end{tabular}

Above table highlights the marked reduction in the number of lymph node biopsies performed at our hospital a decade after increased application of FNA.

Cytohistological correlation was possible in 22 cases from the same lymph node.

Maximum number of correct diagnoses was obtained in metastatic carcinoma ( 5 cases) as seen by Pandit et al ${ }^{11}$ and Narang et al. ${ }^{12}$

In the present series, there were 4 cases of tubercular lymphadenitis diagnosed by histopathology. Two were correctly diagnosed by FNAC. In the remaining two, one was missed as reactive hyperplasia and one as non-Hodgkin's lymphoma.

Out of the 18 cases of lymphoma, biopsy was received in five and diagnosis was confirmed in three cases. Diagnostic accuracy was observed to be $77.27 \%$ in these cases. Ruchi et $\mathrm{al}^{13}$ Gupta et $\mathrm{al}^{14}$ and Tripathi et $\mathrm{al}^{15}$ reported it as $84 \%$, $82 \%$ and $80 \%$ respectively in their study of lymphoma cases. We have found it difficult in two cases to differentiate reactive hyperplasia from lymphoma. The possibility of overlap among reactive hyperplasia, non-Hodgkin's lymphoma and Hodgkin's is also mentioned by Gupta et al ${ }^{14}$ who exclusively studied aspiration smears of lymphoma cases.

One of the most problematic areas in cytology is the distinction between a reactive and neoplastic lymphoid proliferation. ${ }^{1}$ The diagnosis of a malignant lymphoma is straightforward when bizarre or highly pleomorphic lymphoid cells are present in the aspiration smears. ${ }^{1}$ Otherwise, the cytologic diagnosis of malignant lymphomas often is based on the presence of a relatively monomorphic lymphoid population, whereas a polymorphous lymphoid population typically is observed in reactive lymphoid processes. ${ }^{1}$ Potential misdiagnoses may occur when certain lymphomas present with an apparently heterogeneous cellular pattern. ${ }^{1}$

Differentiating HL from NHL is particularly important, since it has direct implications for the prognosis and treatment of patients. ${ }^{16}$ The histologic pictures of their classic forms are sufficiently characteristic to allow for confident differential diagnosis in most cases. ${ }^{16}$ Nonetheless, it was noted that $20 \%$ to $30 \%$ of patients with HL treated with the otherwise successful standard therapy do not respond to treatment and finally die from their disease. ${ }^{16}$ The new methodologies allowing for immunophenotypic and genetic analysis of the neoplasms revealed the existence of lymphomas that did not fit exactly in the categories previously defined, because of a variety of overlapping features. ${ }^{16}$ Such cases with mixed features, a few of which had been reported since the early 1990s were the subject of two workshops and several studies dedicated to these entities, presently referred to as gray-zone lymphomas. 16

Lymphomas that exhibit features overlapping with those of the classical type of HL belong to three groups: (a) Nodular lymphocyte-predominant HL (NLPHL) and T-cell rich large Bcell lymphoma (TCRLBCL); (b) Anaplastic large-cell lymphomas (ALCL; ALK+ and ALK-) and peripheral T-cell lymphoma (PTCL); and (c) Primary mediastinal large-cell Bcell lymphoma (PMLBCL) and diffuse large B-cell lymphoma (DLBCL). 16

1. In NLPHL, the neoplastic cells ( $\mathrm{L}$ and $\mathrm{H}$ cells) are of B-cell type; however, they are clearly different from H/R-S cells of classical HL. 16

2. T-cell rich large B-cell lymphoma may show cells of H/R$\mathrm{S}$ type, but they are of B-cell type and express BCL-2. Eosinophils are not in the background, as in classical or HL, and EBV gene products are not identified. ${ }^{16}$

3. The cells of ALCL tumours, even when similar to H/R-S cells commonly express the T-cell antigens and in most cases the ALK fusion gene which is always negative in HL. The ALK-ALCL lymphomas can be distinguished by the lack of PAX5 antigen, which is usually dimly positive in H/R-S cells. ${ }^{16}$

4. Peripheral T-cell lymphomas express T-cell markers as well as cytotoxic molecules such as granzyme B, whereas HLs are of B-cell origin and do not express T-cell or cytotoxic markers. 16

5. The third group of large B-cell lymphomas constitute the most common overlapping gray zone with HLs, since it is now established that the latter also originate in the Bcells of the lymphoid follicles. ${ }^{16}$ The large B-cell lymphomas arising primarily in the mediastinum originate in the B cells of the thymic medulla and by mediastinal location and histologic similarity may create difficult problems of differential diagnosis with HL. 16 These gray-zone lymphomas share features of DLBCL and of classical HL with expression of CD30, CD15 as well as the pan-B-cell antigens CD20 and CD79a suggesting that they represent a transition between the two tumour types. 16

Gray-zone lymphomas generally exhibit a more aggressive behaviour than their HL counterparts, thus underlining the importance of their differential diagnosis. ${ }^{16}$ They require distinct treatments and the addition of the antiB-cell rituximab antibody to the full combination chemotherapy has been suggested. ${ }^{16}$

\section{CONCLUSION}

Aspiration cytology provides a reliable, safe, rapid and economic method of investigating lymph node enlargement. However, reactive lymphadenitis/ a negative cytology does not rule out serious underlying disorder. This should be considered keeping the overall clinical picture in mind. Also, the diagnostic accuracy can be further improved manifold when used in collaboration with other special techniques like 
cytochemistry, bacteriologic culture, immunocytochemistry, ultrastructural studies and molecular hybridisation.

\section{ACKNOWLEDGEMENT}

The first author would like to thank Dr. Adithya Udupa K for help and support.

\section{REFERENCES}

[1] Yao JL, Cangiarella JF, Cohen JM, et al. Fine-Needle aspiration biopsy of peripheral T-cell lymphomas: a cytologic and immunophenotypic study of 33 cases. Cancer 2001;93(2):151-9.

[2] Friedman M, Kim U, Shimaoka K, et al. Appraisal of aspiration cytology in management of Hodgkin's disease. Cancer 1980;45(7):1653-63.

[3] Orell SR. The techniques of FNA cytology. In: Orell SR, Sterrett GF, Walters MN, et al. Manual and Atlas of fine needle aspiration cytology. $3^{\text {rd }}$ edn. Churchill Livingstone 1999: p. 9-28.

[4] Agarwal D, Bansal P, Rani B, et al. Evaluation of etiology of lymphadenopathy in different age groups using fine needle aspiration cytology: a retrospective study. The Internet Journal of Pathology 2010;10:2.

[5] Patra AK, Nanda BK, Mohapatra BK, et al. Diagnosis of lymphadenopathy by fine needle aspiration cytology. Ind J Pathol Microbiol 1983;26(4):273-8.

[6] El Hag IA, Chiedozi LC, Reyees FA, et al. Fine needle aspiration cytology of head and neck masses seven years' experience in a secondary care hospital. Acta Cytol 2003;47(3):387-92.
[7] Ahmad SS, Akhtar S, Akhtar K, et al. Study of Fine needle aspiration cytology in lymphadenopathy with special reference to acid-fast staining in cases of tuberculosis. JK Science 2005;7(1):1-4.

[8] Hirachand S, Lakhey M, Akther J, et al. Evaluation of fine needle aspiration cytology of lymph nodes in Kathmandu medical college, teaching hospital. Kathmandu University Medical Journal (KUMJ) 2009;7(26):139-42.

[9] Hadju SI, Melamed MR. The diagnostic value of aspiration smears. Am J Clin Path 1973;59:350-6.

[10] Gupta RK, Naran S, Lallu S, et al. Diagnostic value of Fine needle aspiration cytology in the assessment of palpable axillary lymph nodes. A study of 336 cases. Acta Cytol 2003;47(4):550-4.

[11] Pandit AA, Candes FP, Khubchandani SR. Fine needle aspiration cytology of lymph nodes. J Postgrad Med 1987;33(3):134-6.

[12] Narang RK, Pradhan S, Singh RP, et al. Place of fine needle aspiration cytology in the diagnosis of lymphadenopathy. Ind J Tub 1990;37:29-31.

[13] Khajuria R, Goswami KC, Singh K, et al. Pattern of lymphadenopathy on Fine needle aspiration cytology in Jammu. JK Science 2006;8(3):157-9.

[14] Gupta SK, Dutta TK, Aikat BK. Lymph node aspiration biopsy in diagnosis of lymphoma. Ind J Path Microbiol 1997;20:231.

[15] Tripathi SN, Mishra N, Patel NM, et al. Place of aspiration biopsy of lymphadenopathy. Ind J Tuberc $1985 ; 32: 130$

[16] Ioachim HL, Medeiros LJ. Ioachim's Lymph node pathology. $4^{\text {th }}$ edn. Philadelphia: Wolters Kluwer/ Lippincott Williams and Wilkins 2008. 